\title{
Tren dan Faktor Risiko Kematian Maternal di RSUP Dr. Sardjito Yogyakarta Tahun 2012-2017
}

\author{
Uce Siswi Prihesti ${ }^{1}$, Detty Siti Nurdiati², Eugenius Phyowai Ganap ${ }^{3}$ \\ Departemen Obstetri dan Ginekologi \\ Fakultas Kedokteran, Kesehatan Masyarakat dan Keperawatan \\ Universitas Gadjah Mada \\ Korespondensi: uce.siswi.prihesti@gmail.com
}

Submisi: 14 Juni 2019; Revisi: 7 Agustus 2019; Penerimaan: 16 Agustus 2019

\begin{abstract}
Background: Maternal mortality remain high in Indonesia. In 2015 Indonesia aimed to meet the MDG goal of achieving a maternal mortality rate of 102 per 100,000 live births.

Objective: To identify maternal mortality trend and analyze risk factors of maternal deaths in Dr. Sardjito hospital during 2012-2017.

Method: A case control study was perfomed at Dr.Sardjito hospital with maternal mortality cases during 2012-2017 that met the inclusion and exclusion criteria. Controls were match on gestational age and entry of date. The data was analyzed using chi-square statistical tests and logistic regression.

Results and Discussion: In 2012-2017 100 cases of maternal deaths were identified, most of which were caused by preeclampsia, heart disease, other diseases, infection (sepsis), and bleeding (29\%, 25\%, $19 \%, 16 \%$ and $11 \%$ respectively). Indirect cause accounted for $57 \%$ of deaths, while the remaining were contributed by direct causes. We found the increasing trend of maternal mortality rate, with the highest was 2016 (2.670 per 100,000 live births). The most common cause of maternal death during 2012, 2015, 2016 and 2017 was preeclampsia while it was heart diseases during 2013 and 2014. Referral cases (OR 11.67;95\% Cl 4.51-30.19), infections (OR 7.42; 95\% Cl 2.21-24.87) and heart disease (OR 4.02; Cl 95\% 1,65-9.80) significantly affect the incidence of maternal death.
\end{abstract}

Conclusion: Maternal mortality rate Dr.Sardjito hospital during 2012-2017 periods tended to increase, with referral cases, infections and heart disease being the most contributing factors.

Keywords: Maternal mortality; trend and risk factors

\begin{abstract}
ABSTRAK
Latar Belakang: Kematian maternal merupakan masalah obstetrik besar di Indonesia. Pada tahun 2015 MDG's menargetkan angka kematian ibu di Indonesia sebesar 102 per 100.000 kelahiran hidup.

Tujuan: Untuk mengetahui tren dan menganalisis faktor risiko yang menyebabkan kematian maternal di RSUP dr. Sardjito tahun $2012-2017$.

Metode:Penelitian ini menggunakan metode kasus kontrol di RSUP Dr. Sardjito dengan sampel kasus maternal yang meninggal pada tahun 2012-2017 yang memenuhi kriteria inklusi dan eksklusi. Kontrol diambil dengan melakukan matching dengan umur kehamilan dan tanggal masuk rumah sakit, besarnya masing-masing 100 sampel. Data dianalisis menggunakan uji statistik chi-square dan regresi logistik.

Hasil dan Pembahasan: Pada tahun 2012-2017 terdapat 100 kematian maternal dengan penyebab utama adalah preeklampsia 29\%, penyakit jantung $25 \%$, penyakit lain $19 \%$, infeksi (sepsis) $16 \%$, dan perdarahan $11 \%$. Dengan penyebab kematian langsung $43 \%$ dan tidak langsung $57 \%$. Pada penelitian ini tren angka kematian ibu per 100.000 kelahiran hidup cenderung meningkat, tertinggi pada tahun 2016 sebesar 2670 per 100.000 kelahiran hidup. Sedangkan penyebab kematian maternal terbanyak pada tahun 2012, 2015, 2016 dan 2017 adalah preeklampsia sedangkan pada tahun 2013 dan 2014 adalah penyakit jantung. Kasus rujukan (OR 11,67; Cl 95\% 4,51-30,19), infeksi (OR 7,42; Cl 95\% 2,21-24,87) dan penyakit jantung (OR 4,02; Cl95\% $1,65-9,80)$ berpengaruh secara signifikan terhadap kejadian kematian maternal.
\end{abstract}

Kesimpulan: Tren kematian maternal di RSUP Dr. Sardjito Yogyakarta tahun 2012-2017 cenderung meningkat. Kasus rujukan, infeksi dan penyakit jantung berpengaruh meningkatkan kejadian kematian maternal di RSUP Dr. Sardjito Yogyakarta tahun 2012-2017.

Kata Kunci: Kematian maternal; tren dan faktor risiko 


\section{PENDAHULUAN}

Tingginya angka mortalitas maternal menjadi salah satu hal yang perlu diberi perhatian lebih. Dengan kisaran adanya 830 kematian pada wanita di seluruh dunia setiap harinya, dan pada akhir tahun 2015 tercatat sebanyak 303.000 wanita meninggal baik yang diakibatkan oleh komplikasi yang terjadi pada saat kehamilan maupun pada saat proses persalinan. ${ }^{1}$

Angka kematian ibu di Indonesia diperkirakan 300-400 per 100.000 kelahiran hidup, yang berarti bahwa di Indonesia seorang ibu meninggal setiap jam baik karena kehamilan itu sendiri, komplikasi saat persalinan, rujukan yang terlambat ke rumah sakit, ataupun pelayanan darurat obstetri yang kurang baik. Penyebab kematian maternal di Indonesia sebanyak $28 \%$ disebabkan oleh perdarahan, preeklampsia dan eklampsia (24\%), infeksi atau sepsis (11\%), komplikasi akibat abortus $(6 \%)$, persalinan terhambat (5\%), dan penyebab lain $(26 \%)^{2}$

Berdasarkan kemenkes RI tahun 2014 terdapat lima penyebab kematian maternal terbesar di Indonesia yaitu perdarahan, hipertensi dalam kehamilan, infeksi, partus lama dan abortus. Kematian ibu di Indonesia masih didominasi oleh tiga penyebab utama yaitu perdarahan, hipertensi dalam kehamilan, dan infeksi. ${ }^{3}$

Salah satu penelitian di RSUP dr. Sardjito, yang dilakukan selama 7 bulan dengan menggunakan kontrol ibu yang hampir meninggal dengan tiga variabel yang diukur yaitu ketepatan waktu perawatan, kepatuhan terhadap standar operasional prosedur, dan variabel luar yang terkait. Hasil dari penelitian tersebut salah satunya adalah ibu yang meninggal atau nyaris meninggal sebagian besar merupakan pasien rujukan dari fasilitas perawatan kesehatan lainnya (OR 0,09; $95 \% \mathrm{Cl} 0,01-0,91$ ). Sehingga diperlukan sistem rujukan yang tepat untuk mencegah kematian ibu. ${ }^{4}$

RSUP Dr. Sardjito merupakan rumah sakit dengan rujukan tertinggi terutama untuk daerah DI Yogyakarta dan Jawa Tengah bagian Selatan. Hal ini tidak menutup kemungkinan terjadinya peningkatan kasus-kasus dengan kompleksitas yang tinggi. Selain itu sebagai dampak pemberlakuan rujukan berjenjang akan mengakibatkan peningkatan kasus yang terindikasi untuk dirujuk dan ditangani di rumah sakit tipe $A$, sehingga pasien yang dirawat di RSUP Dr. Sardjito merupakan pasien dengan kondisi penyakit berat sehingga akan meningkatkan kejadian kematian maternal

RSUP Dr. Sardjito Yogyakarta. Dengan demikian, dibutuhkan data yang terbaru mengenai penyebab kematian maternal di RSUP Dr. Sardjito, dengan tujuan untuk memberikan data terbaru guna mencegah terjadinya kemtian maternal.

Tujuan dari penelitian ini adalah untuk mengetahui tren kematian maternal dan faktor risiko yang menyebabkan kematian maternal di RSUP Dr. Sardjito Yogyakarta tahun 2012-2017.

\section{METODE}

Penelitian ini adalah penelitian non eksperimental dengan metode kasus kontrol. Penelitian ini menggunakan data yang diambil dari rekam medis RSUP dr. Sardjito dengan populasi adalah semua pasien hamil, bersalin dan nifas yang dirawat di RSUP dr. Sardjito selama periode penelitian. Subyek penelitian adalah semua kasus kematian maternal yang terjadi di RSUP Dr. Sardjito pada tahun 20122017, kecuali yang diakibatkan karena pembunuhan atau kecelakaan.

Variabel tergantung pada penelitian ini adalah kematian maternal (ya/tidak) dengan variabel bebas pre-eklampsia/eklampsia, perdarahan, infeksi, dan penyakit jantung. Sedangkan variabel luar adalah umur, status paritas, status rujukan, status pembiayaan pasien (asuransi kesehatan), tempat tinggal, metode persalinan, dan kadar $\mathrm{Hb}$ saat masuk RS.

Analisis data yang digunakan adalah uji analisis univariat, bivariat serta multifariat. Uji statistik yang digunakan untuk analisis bivariat adalah uji Chisquare. Uji statistik yang digunakan untuk analisis multivariat adalah uji regresi logistik. Pengolahan data untuk pengujian statistic menggunakan SPSS 21.

\section{HASIL DAN PEMBAHASAN}

\section{Analisis Univariat}

Selama tahun 2012-2017, terdapat total 100 kematian maternal di RSUP dr. Sardjito Yogyakarta. 
Kontrol pada penelitian ini diambil 100 sampel dengan dilakukan pencocokan dengan umur kehamilan dan tanggal saat masuk rumah sakit.

a. Karakteristik Sampel Penelitian

Dari penelitian ini didapatkan bahwa sebagian besar pasien berumur 20-35 tahun. Pekerjaan pasien terbanyak dalam kategori lain-lain dengan tingkat pendidikan sebagian besar lulus SLTP. Pada penelitian ini pasien terbanyak pada tahun 2012 (22\%) dan menurun pada tahun 2013 (7\%) dan meningkat lagi mencapai 19,5\% dan 20,5\% pada tahun 2016 dan 2017 (Tabel 1).

b. Karakteristik sosial ekonomi dan fasilitas kesehatan

Pasien terbanyak adalah pasien rujukan yaitu rujukan dari rumah sakit tipe $B(68 \%)$ diikuti tipe $C(54 \%)$ yang sebagian besar berasal dari daerah Yogyakarta (65\%). Mayoritas pasien membayar dengan menggunakan asuransi kesehatan yaitu JKN (59\%), Jampersal (14,5\%) sedangkan pasien yang membayar tanpa asuransi kesehatan atau umum (26,5\%). Penolong persalinan pasien yang paling banyak adalah dokter spesialis (58\%) dan residen (24,5\%). Tempat perawatan pasien sampai dengan meninggal terbanyak di ICU 66 (33\%). Pasien yang meninggal di ICU terbanyak disebabkan oleh preeklampsia $39,4 \%$ (Tabel 2).

c. Karakteristik kondisi ibu

Sebagian besar pasien kedua kelompok nullipara atau primipara $(69,5 \%)$ dengan usia kehamilan preterm (75.5\%). Metode persalinan yang paling sering adalah persalinan secara abdominal $(52,5 \%)$ dan kadar hb saat masuk rumah sakit sebagian besar normal (55\%). Terjadinya kematian ibu sebagian besar pada pasien setelah melahirkan (77\%) (Tabel 3).
Tabel 1. Karakteristik pasien

\begin{tabular}{lrc}
\hline \multirow{2}{*}{ Variabel } & \multicolumn{2}{c}{ Populasi } \\
\cline { 2 - 3 } & $\mathbf{N}$ & $\%$ \\
\hline Usia pasien & 9 & 4,5 \\
$<20$ tahun & 46 & 23 \\
>35 tahun & 145 & 72,5 \\
20-35 tahun & & \\
Pekerjaan & 15 & 7,5 \\
Petani/buruh & 43 & 21,5 \\
Pegawai (PNS, non PNS, TNI, POLRI) & 9,5 \\
Wiraswasta & 19 & 61,5 \\
Lain-lain & 123 & \\
Pendidikan & & \\
Lulus SLTP & 174 & 87 \\
Tidak lulus SLTP & 26 & 13 \\
Tahun kejadian & & \\
2012 & & \\
2013 & 44 & 22 \\
2014 & 14 & 7 \\
2015 & 40 & 20 \\
2016 & 22 & 11 \\
2017 & 39 & 19,5 \\
& 41 & 20,5 \\
\hline
\end{tabular}

Tabel 2. Karakteristik sosial ekonomi dan fasilitas kesehatan pasien yang digunakan sebagai sampel penelitian

\begin{tabular}{|c|c|c|}
\hline \multirow{2}{*}{ Variabel } & \multicolumn{2}{|c|}{ Populasi } \\
\hline & $\mathbf{N}$ & $\%$ \\
\hline \multicolumn{3}{|l|}{ Rujukan } \\
\hline Rujukan & 152 & 76 \\
\hline Tidak dirujuk & 48 & 24 \\
\hline \multicolumn{3}{|l|}{ Asal Rujukan } \\
\hline RS tipe A & 7 & 3,5 \\
\hline RS tipe B & 68 & 34 \\
\hline RS tipe C & 54 & 27 \\
\hline RS tipe D & 9 & 4,5 \\
\hline Puskesmas & 7 & 3,5 \\
\hline Balai kesehatan & 2 & 1 \\
\hline BPM & 4 & 2 \\
\hline Lain-lain/tidak dirujuk & 49 & 24,5 \\
\hline \multicolumn{3}{|l|}{ Status Pembayaran } \\
\hline JKN & 118 & 59 \\
\hline Jampersal & 29 & 14,5 \\
\hline Umum & 53 & 26,5 \\
\hline \multicolumn{3}{|l|}{ Penolong Persalinan } \\
\hline Bidan & 11 & 5,5 \\
\hline Residen & 49 & 24,5 \\
\hline Dokter Spesialis & 11,6 & 58 \\
\hline Lain-lain & 24 & 12 \\
\hline \multicolumn{3}{|l|}{ Alamat } \\
\hline Yogyakarta & 130 & 65 \\
\hline Luar Yogyakarta & 70 & 35 \\
\hline
\end{tabular}


Tabel 3. Karakteristik kondisi ibu

\begin{tabular}{lrc}
\hline \multirow{2}{*}{ Variabel } & \multicolumn{2}{c}{ Populasi } \\
\cline { 2 - 3 } & N & $\%$ \\
\hline Paritas & & \\
Primipara/nullipara & 139 & 69,5 \\
Multipara & 59 & 29,5 \\
Grand multipara & 2 & 1 \\
Hb Saat Masuk & & \\
Anemia berat & 7 & 3,5 \\
Anemia sedang & 12 & 6 \\
Anemia ringan & 7 & 35,5 \\
Normal & 110 & 55 \\
Usia Kehamilan & & \\
Preterm & 151 & 75,5 \\
Aterm & 25 & 12,5 \\
Fullterm & 22 & 11 \\
Lateterm & 2 & 1 \\
Posterm & 0 & 0 \\
Metode Persalinan & & \\
Abdominal & & \\
Kelahiran vaginal operatif & 105 & 52,5 \\
Kelahiran vaginal spontan & 8 & 4 \\
Terjadinya Kematian Ibu & 63 & 31,5 \\
Sebelum melahirkan & & \\
Setelah melahirkan & 23 & 23 \\
\hline
\end{tabular}

\section{Tren Kematian Maternal di RSUP dr. Sardjito Yogyakarta Tahun 2012-2017}

Pada penelitian ini didapatkan sejumlah 100 sampel kematian maternal yang terjadi di RSUP dr. Sardjito Yogyakarta pada kurun waktu tahun 2012-
2017. Pada penelitian ini tren kematian maternal cenderung meningkat. Jumlah kematian ibu per 100.000 kelahiran hidup pada tahun 2012 sebesar 1477 ibu dan menurun pada tahun 2013 menjadi 501 ibu dan kemudian mengalami peningkatan kembali pada tahun 2014 menjadi sebesar 1664 ibu. Pada tahun 2015 sedikit mengalami penurunan yaitu sebesar 1287 ibu dan meningkat lagi mencapai 2670 ibu pada tahun 2016 dan 2301 ibu pada tahun 2017 (gambar 1)

Tren penyebab kematian maternal di RSUP dr. Sardjito Yogyakarta tahun 2012,2015, 2016 dan 2017 terbanyak disebabkan oleh PEB sedangkan pada tahun 2013 dan 2014 disebabkan oleh penyakit jantung.

Kematian maternal yang terjadi di RSUP Dr. Sardjito terbanyak berturut-turut disebabkan oleh Preeklampsia (29\%), penyakit jantung (25\%), penyakit lain (19\%), infeksi atau sepsis (16\%) dan perdarahan (11\%).

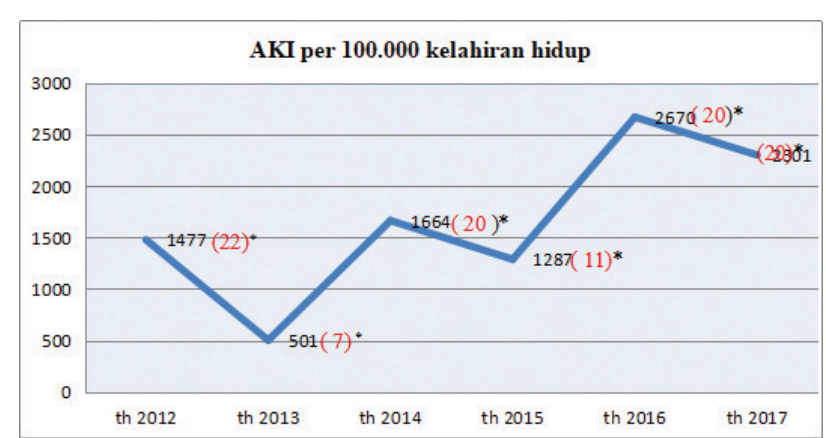

Gambar 1. Tren Kematian Maternal 2012-2017

Tabel 4. Hasil analisis kejadian kematian maternal terhadap terhadap variabel bebas

\begin{tabular}{|c|c|c|c|c|c|c|c|c|}
\hline & & \multicolumn{4}{|c|}{ Kelompok } & \multirow{3}{*}{$\mathbf{p}$} & \multirow{3}{*}{ OR } & \multirow{3}{*}{ Cl 95\% } \\
\hline & & \multicolumn{2}{|c|}{ Meninggal } & \multicolumn{2}{|c|}{ Hidup } & & & \\
\hline & & $\mathbf{N}$ & $\%$ & $\mathbf{N}$ & $\%$ & & & \\
\hline \multirow[t]{2}{*}{ PEB } & Tidak & 71 & 71 & 73 & 73 & & 1 & \\
\hline & Ya & 29 & 29 & 27 & 27 & 0,753 & 1,11 & $0,59-2,05$ \\
\hline \multirow[t]{2}{*}{ Infeksi } & Tidak & 84 & 84 & 93 & 93 & & 1 & \\
\hline & Ya & 16 & 16 & 7 & 7 & 0,046 & 2,53 & $0,99-6,45$ \\
\hline \multirow[t]{2}{*}{ Perdarahan } & Tidak & 89 & 89 & 93 & 93 & & 1 & \\
\hline & Ya & 11 & 11 & 7 & 7 & 0,323 & 1,64 & $0,61-4,42$ \\
\hline \multirow[t]{2}{*}{ Jantung } & Tidak & 75 & 75 & 86 & 86 & & 1 & \\
\hline & Ya & 25 & 25 & 14 & 14 & 0,050 & 2,05 & $0,99-4,22$ \\
\hline
\end{tabular}

*angka kematian absolut 


\section{Pengaruh Jenis Penyakit Terhadap Terjadinya Kematian}

Penelitianinimelihathubunganjenispenyakit dengan kejadian kematian maternal dengan menggunakan uji chi square dengan derajat kemaknaan $p<0,05$ dan tingkat kepercayaan 95\%. Berdasarkan tabel 4 diketahui bahwa tidak ada pengaruh yang bermakna terhadap kejadian kematian maternal pada pasien preeklampsia, jantung dan perdarahan $(p>0,05)$. Sedangkan infeksi $(p=0,046)$ berpengaruh bermakna terhadap kejadian kematian maternal $(p<0,05)$ dengan risiko untuk infeksi sebesar 2,53 kali.

a. Pengaruh faktor risiko lain terhadap kejadian kematian maternal
Pada penelitian ini, kasus rujukan berpengaruh secara signifikan terhadap kejadian kematian maternal. Perbedaan ini bermakna yang ditunjukkan oleh nilai $p=0,000 \quad(p<0,05)$, $\mathrm{OR}=6,46$ yang berarti pasien rujukan berisiko meninggal 6,46 kali (tabel 5).

Terdapat perbedaan bermakna kematian maternal antara yang dari Yogyakarta dan luar Yogyakarta $p<0,05$. Sedangkan umur, paritas, status pembayaran, $\mathrm{Hb}$ saat masuk RS dan metode persalinan tidak signifikan berpengaruh terhadap kejadian kematian maternal.

Tabel 5. Hasil analisis faktor risiko lain terhadap kejadian kematian maternal

\begin{tabular}{|c|c|c|c|c|c|c|c|c|}
\hline & \multirow{3}{*}{ Variabel } & \multicolumn{4}{|c|}{ Kelompok } & \multirow{3}{*}{$\mathbf{P}$} & \multirow{3}{*}{ OR } & \multirow{3}{*}{$\mathrm{Cl} 95 \%$} \\
\hline & & \multicolumn{2}{|c|}{ Meninggal } & \multicolumn{2}{|c|}{ Hidup } & & & \\
\hline & & $\mathbf{N}$ & $\%$ & $\mathbf{n}$ & $\%$ & & & \\
\hline \multirow[t]{3}{*}{ Umur } & 20-35 tahun & 73 & 73 & 72 & 72 & & 1 & \\
\hline & $<20$ tahun & 3 & 3 & 6 & 6 & 0,330 & 0,49 & $0,12-2,05$ \\
\hline & $>35$ tahun & 24 & 24 & 22 & 22 & 0,829 & 1,08 & $0,55-2,09$ \\
\hline \multirow[t]{2}{*}{ Rujukan } & Tidak dirujuk & 9 & 9 & 39 & 39 & & 1 & \\
\hline & Rujukan & 91 & 91 & 61 & 61 & 0,000 & 6,46 & $2,92-14,3$ \\
\hline \multirow[t]{2}{*}{ Alamat } & Yogyakarta & 58 & 58 & 72 & 72 & & 1 & \\
\hline & Luar Yogyakarta & 42 & 42 & 28 & 28 & 0,038 & 1,86 & $1,03-3,36$ \\
\hline Status & Umum & 22 & 22 & 31 & 31 & & 1 & \\
\hline \multirow[t]{2}{*}{ Pambayaran } & JKN & 63 & 63 & 55 & 55 & 0,152 & 1,61 & $0,84-3,11$ \\
\hline & Jampersal & 15 & 15 & 14 & 14 & 0,375 & 1,51 & $0,61-3,75$ \\
\hline \multirow[t]{3}{*}{ Paritas } & Primi/nulipara & 67 & 67 & 72 & 72 & & 1 & \\
\hline & Multipara & 32 & 32 & 27 & 27 & 0,960 & 1,07 & $0,66-17,52$ \\
\hline & Grand multipara & 1 & 1 & 1 & 1 & 0,438 & 1,27 & $0,69-2,34$ \\
\hline \multirow{4}{*}{$\begin{array}{l}\text { Hb saat } \\
\text { masuk RS }\end{array}$} & Normal & 55 & 55 & 55 & 55 & & 1 & \\
\hline & Anemia berat & 6 & 6 & 1 & 1 & 0,102 & 6,00 & $0,69-51,49$ \\
\hline & Anemia sedang & 7 & 7 & 5 & 5 & 0,585 & 1,40 & $0,42-4,68$ \\
\hline & Anemia ringan & 32 & 32 & 39 & 39 & 0,517 & 0,82 & $0,45-1,49$ \\
\hline \multirow{3}{*}{$\begin{array}{l}\text { Metode } \\
\text { Persalinan }\end{array}$} & Kelahiran vaginal & 24 & 24 & 39 & 39 & & 1 & \\
\hline & spontan & 51 & 51 & 54 & 54 & 0,187 & 1,54 & $0,81-2,90$ \\
\hline & $\begin{array}{l}\text { Abdominal } \\
\text { Kelahiran vaginal } \\
\text { operatif }\end{array}$ & 3 & 3 & 5 & 5 & 0,974 & 0,97 & $0,213-4,45$ \\
\hline
\end{tabular}

b. Pengaruh jenis penyakit terhadap saat terjadinya kematian ibu

Kematian pada ibu dengan PEB lebih banyak terjadi setelah melahirkan (33,8\%) dibandingkan dengan saat hamil (13\%), dengan perbedaan yang tidak bermakna $(p=0,055)$. Ibu dengan penyakit jantung lebih banyak meninggal setelah melahirkan $(29,9 \%)$ dibandingkan yang belum melahirkan $(8,7 \%)$ dengan perbedaan bermakna $(p=0,040)$. Pasien dengan infeksi 
berisiko meningkatkan kejadian kematian ibu pada saat hamil $(p=0,000)$. Kematian ibu dengan perdarahan lebih banyak terjadi pada pasien setelah melahirkan (13\%), tetapi tidak ada perbedaan yang bermakna.

Tabel 6. Hasil analisis variabel bebas terhadap terjadinya kematian ibu

\begin{tabular}{|c|c|c|c|c|c|c|c|c|}
\hline \multirow{3}{*}{ Variabe } & & \multicolumn{4}{|c|}{ Terjadinya Kematian Ibu } & \multirow{3}{*}{$\mathbf{p}$} & \multirow{3}{*}{ OR } & \multirow{3}{*}{ Cl 95\% } \\
\hline & & \multicolumn{2}{|c|}{ Saat Hamil } & \multicolumn{2}{|c|}{ Post-Partum } & & & \\
\hline & & $\mathbf{N}$ & $\%$ & $\mathbf{N}$ & $\%$ & & & \\
\hline \multirow[t]{2}{*}{ PEB } & Tidak & 20 & $87 \%$ & 51 & $66,2 \%$ & & 1 & \\
\hline & Ya & 3 & $13 \%$ & 26 & $33,8 \%$ & 0,055 & 0,294 & $0,08-1,08$ \\
\hline \multirow[t]{2}{*}{ Infeksi } & Tidak & 13 & $56,5 \%$ & 71 & $92,2 \%$ & & 1 & \\
\hline & Ya & 10 & $43,5 \%$ & 6 & $7,8 \%$ & 0,000 & 9,103 & $2,82-29,39$ \\
\hline \multirow[t]{2}{*}{ Jantung } & Tidak & 21 & $91,3 \%$ & 54 & $70,1 \%$ & & 1 & \\
\hline & Ya & 2 & $8,7 \%$ & 23 & $29,9 \%$ & 0,040 & 0,224 & $0,48-1,13$ \\
\hline \multirow[t]{2}{*}{ Perdarahan } & Tidak & 22 & $95,7 \%$ & 67 & $87,0 \%$ & & & \\
\hline & Ya & 1 & $4,3 \%$ & 10 & $13,0 \%$ & 0,245 & 0,305 & $0,04-2,51$ \\
\hline
\end{tabular}

\section{Analisis Multivariat}

Hasil mutivariat dengan regresi logistik dengan metode backward pada hasil analisis terakhir diketahui bahwa penyebab kematian ibu yang bermakna yaitu infeksi $p=0,001$ dan penyakit jantung $p=0,002$ dengan risiko kematian maternal pada infeksi sebesar 7,42 kali dan penyakit jantung sebesar 4,02 kali dibandingkan penyakit lain. Rujukan berpengaruh signifikan terhadap kematian maternal $p=0,000$ dengan risiko sebesar 11,67 kali. Besarnya pengaruh ketiga variabel yaitu infeksi, penyakit jantung dan rujukan terhadap kematian maternal sebesar $29,5 \%$ sedangkan sisanya dipengaruhi faktor lain diluar penelitian

Tabel 7. Analisis multivariat dengan regresi logistik

\begin{tabular}{|c|c|c|c|c|c|c|c|c|}
\hline & & \multicolumn{4}{|c|}{ Kelompok } & \multirow{3}{*}{$p$} & \multirow{3}{*}{ OR } & \multirow{3}{*}{ Cl 95\% } \\
\hline & & \multicolumn{2}{|c|}{ Meninggal } & \multicolumn{2}{|c|}{ Hidup } & & & \\
\hline & & $\mathbf{N}$ & $\%$ & $\mathbf{N}$ & $\%$ & & & \\
\hline \multirow[t]{2}{*}{ Infeksi } & Tidak & 84 & 84 & 93 & 93 & & 1 & \\
\hline & Ya & 16 & 16 & 7 & 7 & 0,001 & 7,42 & $2,21-24,87$ \\
\hline \multirow[t]{2}{*}{ Jantung } & Tidak & 75 & 75 & 86 & 86 & & 1 & \\
\hline & Ya & 25 & 25 & 14 & 14 & 0,002 & 4,02 & $1,65-9,80$ \\
\hline \multirow[t]{2}{*}{ Rujukan } & Tidak & 9 & 9 & 39 & 39 & & 1 & \\
\hline & $\mathrm{Ya}$ & 91 & 91 & 61 & 61 & 0,000 & 11,67 & $4,51-30,19$ \\
\hline
\end{tabular}

Pada penelitian ini, tren kematian maternal di RSUP dr. Sardjito tahun 2012-2017 cenderung meningkat. Faktor risiko yang berpengaruh secara signifikan terhadap kejadian kematian maternal adalah pasien rujukan, penyakit jantung, dan infeksi (sepsis).
Pada penelitian ini, pasien yang meninggal sebagian besar adalah pasien rujukan, dan berasal dari rujukan rumah sakit sekunder yaitu tipe B dan C. Pada penelitian sebelumnya pada fasilitas kesehatan pusat rujukan di Nigeria, dimana pasien yang dirujuk memiliki risiko 3-4 kali terjadinya kematian 
maternal, disertai dengan risiko lain seperti tempat melahirkan di fasilitas sekunder, multiparitas dan adanya riwayat keguguran sebelumnya. ${ }^{5}$

Penelitian yang dilakukan di RSUP dr. Sardjito Yogyakarta sebelumnya menunjukkan bahwa ibu yang meninggal atau nyaris meninggal di RSUP dr. Sardjito sebagian besar merupakan pasien rujukan dari fasilitas perawatan kesehatan lainnya (OR 0,09; $95 \% \mathrm{Cl} 0,01-0,91)$. Hal ini disebabkan keadaan umum yang buruk saat pasien dirujuk dan keterlambatan dalam merujuk. ${ }^{4}$

Pada penelitian ini kasus-kasus rujukan berpengaruh secara signifikan terhadap kejadian kematian maternal (OR=11,67; 95\% Cl 4,5130,2). Hal ini disebabkan ibu yang dirujuk dari fasilitas kesehatan lain, dengan kondisi umum ibu yang mengalami komplikasi kelahiran yang berat, keterlambatan merujuk dan keterlambatan mengenali kasus maternal dengan kegawatan obstetrik pada rumah sakit di bawah level tersier.

Sepsis atau infeksi merupakan salah satu penyebab kematian maternal. Definisi infeksi sebagai penyebab kematian maternal terbagi manjadi dua yaitu penyebab kematian langsung dan penyebab kematian tidak langsung. Pada penelitian ini sebanyak $16 \%$ kematian maternal diakibatkan oleh sepsis atau infeksi sebagai penyebab kematian tidak langsung. ${ }^{6}$

Menurut Verma, dari hasil penelitan di rumah sakit tersier yang menjadi rujukan dari 9 rs primer (rumah sakit umum dan rumah sakit swasta) di India, kematian maternal terjadi pada $62,6 \%$ memerlukan perawatan di ICU, dengan penyebab kematian terbanyak adalah sepsis $(52,2 \%)$, diikuti dengan perdarahan $(17,4 \%)$, penyakit jantung $(17,4 \%)$ dan hipertensi $(4,3 \%)$. Terdapat 5 kasus sepsis pada tahun 2011 (3 kasus karena infeksi H1N1 dengan pneumonia,1 kasus karena pneumonia virus, dan sisanya karena pyelonephritis) dan 7 kasus pada tahun 2012 (5 kasus karena infeksi setelah operasi seksio sesarea, 1 kasus H1N1 dan 1 kasus infeksi hepatitis. Faktor risiko yang mempengaruhi kematian maternal tersebut adalah ANC yang tidak teratur, infrastruktur rumah sakit yang buruk, kualitas kemampuan tenaga kesehatan yang kurang, rujukan yang terlambat. ${ }^{7}$
Pada penelitian ini, kejadian infeksi memiliki OR 12 kali lebih besar menyebabkan kematian maternal dibandingkan tanpa kejadian infeksi.

Pada sebuah penelitian di RS tersier Thailand, RS Songklanagarind tahun 1995 sampai 2016, terdapat 331 kasus, 157 kasus dengan penyakit jantung kongenital dan 174 kasus dengan penyakit jantung didapat. Gagal jantung merupakan komplikasi yang paling sering pada kehamilan. Angka kematian ibu 3,6\% disebabkan karena penyakit jantung dengan WHO class IV. Penyakit jantung merupakan penyebab utama kematian maternal dinegara maju maupun negara berkembang dengan variasi jumlah 1-4\%. Kehamilan akan meyebabkan perubahan pada system hemodinamik ibu, dengan meningkatnya jumlah blood volume, cardiac output, menurunnya resistensi vascular sistemik dan tekanan darah. Hal ini akan menyebabkan peningkatan mortalitas ibu dan bayi. ${ }^{8}$

Di RSUP dr. Sardjito angka kematian maternal yang disebabkan penyakit jantung semakin meningkat setelah diberlakukan sistem jaminan kesehatan nasional, hal ini disebabkan karena RSUP dr. Sardjito merupakan RS tersier, dimana penyakit jantung dengan kehamilan sudah seharusnya mendapatkan perawatan yang intensif di RS tingkat tersier. Pada penelitian ini penyakit jantung menyebabkan kematian maternal terbanyak sebesar $25 \%$ dan secara statistik mempunyai pengaruh yang signifikan terhadap kejadian kematian maternal.

\section{KESIMPULAN DAN SARAN}

Pada penelitian ini disimpulkan bahwa tren kematian maternal di RSUP dr. Sardjito Yogyakarta tahun 2012-2017 cenderung meningkat. Penyebab kematian maternal terbanyak di RSUP dr. Sardjito adalah preeklampsia 29 (29\%), penyakit jantung 25 (25\%), penyakit lain 19 (19\%), infeksi (sepsis) 16 (16\%) dan perdarahan 11 (11\%). Faktor risiko yang berpengaruh secara signifikan terhadap kejadian kematian maternal adalah status pasien rujukan, penyakit jantung, dan infeksi (sepsis).

\section{DAFTAR PUSTAKA}

1. World Health Organization. 2018. WHO_Maternal mortality. World Health Organization Fact Sheets Maternal Mortality. 
2. UNFPA Indonesia. 2018. Maternal Mortality RatioIndonesia.

3. Kementerian Kesehatan RI. 2012. Profil Kesehatan Indonesia [Internet]. Kementerian Kesehatan Republik indonesia. Jakarta: Kementerian Kesehatan RI; 2014. 1-382 p. Available from: http://www. depkes.go.id/resources/download/pusdatin/ profil-kesehatan-indonesia/profil-kesehatanindonesia-2012.pdf

4. Mawarti Y, Utarini A, Hakimi M. 2017. Maternal care quality in near miss and maternal mortality in an academic public tertiary hospital in Yogyakarta, Indonesia: A retrospective cohort study. BMC Pregnancy Childbirth. BMC Pregnancy and Childbirth; 2017;17(1):1-8.

5. Ntoimo LF, Friday E, Rosemary N, Galadanci HS, Gana $\mathrm{M}$, Ola N, et al. 2018. Prevalence and risk factors for maternal mortality in referral hospitals in Nigeria : a multicenter study. 2018;69-76.
6. Ngonzi J, Tornes YF, Mukasa PK, Salongo W, Kabakyenga J, Sezalio M, et al. 2016. Puerperal sepsis, the leading cause of maternal deaths at a Tertiary University Teaching Hospital in Uganda. BMC Pregnancy Childbirth. BMC Pregnancy and Childbirth; 2016;1-7.

7. Ps R, Verma S, Rai L, Kumar P, Pai M V, Shetty J.2013. "“ Near Miss "' Obstetric Events and Maternal Deaths in a Tertiary Care Hospital : An Audit. 2013;2013:105.

8. Suwanrath $C$, Thongphanang $P$, Pinjaroen $S$, Suwanugsorn S. 2018. Validation of modified World Health Organization classification for pregnant women with heart disease in a tertiary care center in southern Thailand. Dovepress. 2018;47-53. 